\title{
Justiça militar brasileira: persecução contra civis negros, pobres e favelados em operação de garantia da lei e da ordem no Rio de Janeiro
}

Justicia militar brasileña: persecución de civiles negros y pobres de favelas en función de la garantía de la ley y el orden en Río de Janeiro

Brazilian Military Justice: Persecution againt Black, Poor and Slaughters Civils, in Operation of Law and Orden Guarantee in Río de Janeiro

Jorge Rubem Folena de Oliveira Diretor

Instituto dos Advogados Brasileiros

Brasil

Recibido: 10/08/2020 - Aceptado: 08/09/2020 Os militares exercem forte influência na vida política brasileira desde a proclamação da República, em 1889. A Justiça Militar, que deveria julgar exclusivamente militares em tempo de paz, ao longo da História do Brasil tem sido empregada para condenar civis, inclusive por razões de perseguição política. Nos últimos anos tem sido constatada a condenação de ci-

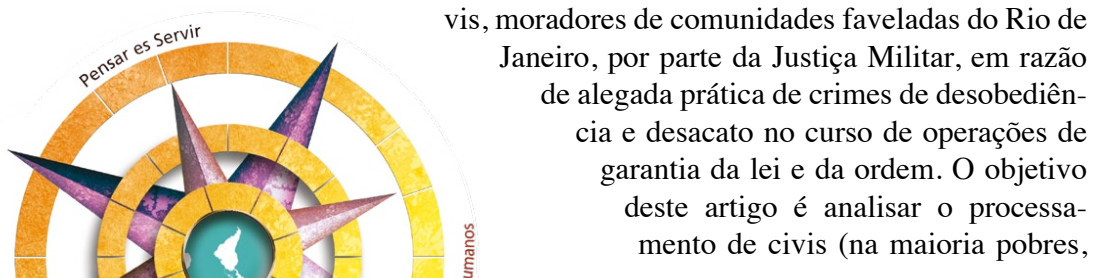

Doi: https://doi.org/10,15359/tdna.36-68.3 
negros e favelados no Rio de Janeiro), por parte da Justiça militar, em operações de cumprimento da Lei e da Ordem, por enquadramento nos crimes de desobediência e desacato praticados contra militares. A investigação ocorreu por meio de análise qualitativa de acórdãos do Superior Tribunal Militar, entre os anos de 2011 a 2019, em condenações por desobediência e desacato, no curso de operações de Garantia da Lei e da Ordem empregadas contra moradores de comunidades faveladas do Rio de Janeiro, que se insurgiram contra a atuação policial das Forças Armadas.

Palavras-chaves: Justiça Militar. Colonialismo. Subalternidade. GLO. Garantia da lei e da ordem. Resistência e Desacato.

\title{
Resumen
}

Los militares han tenido una fuerte influencia en la vida política brasileña desde la proclamación de la República en 1889. La justicia militar, que debe juzgar exclusivamente a los militares en tiempo de paz, se ha empleado a lo largo de la historia del Brasil para condenar a civiles, incluso por motivos de persecución política. En los últimos años, la Justicia Militar ha constatado que se ha condenado a civiles que viven en comunidades de favelas de Río de Janeiro por supuestos delitos de desobediencia y desacato en el curso de operaciones para garantizar el orden público. El objetivo de este artículo es analizar el enjuiciamiento de civiles (en su mayoría pobres, negros y residentes de favelas en Río de Janeiro) por la justicia militar en el curso de operaciones de aplicación de la ley y el orden por delitos de desobediencia y desacato cometidos contra personal militar. La investigación se llevó a cabo mediante un análisis cualitativo de las decisiones del Tribunal Militar Superior, de 2011 a 2019, en condenas por desobediencia y desacato, en el curso de operaciones de aplicación de la ley y el orden contra residentes de comunidades de favelas en Río de Janeiro, que insistieron en contra de la acción policial de las Fuerzas Armadas.

Palabras clave: Justicia militar, colonialismo, subalternidad, GLO, garantía de ley y de orden, resistencia y desacato

\begin{abstract}
The military has had a strong influence on Brazilian political life since the proclamation of the Republic in 1889. Military Justice, which should judge exclusively military personnel in peacetime, throughout Brazil's history has been used to condemn civilians, including for reasons of political persecution. In recent years there has been the condemnation of civilians, residents of favela communities in Rio de Janeiro, by the Military Justice as result of alleged crimes of disobedience and contempt in the course of law and order guarantee operations. The purpose of this article is to analyze the prosecution by the military justice of civilians (mostly poor, black and slum dwellers in Rio de Janeiro), in the course of law and order compliance operations, for
\end{abstract}

36 Justiça militar brasileira: persecução contra civis negros, pobres e favelados em operação de garantia da lei e da ordem no Rio de Janeiro Dr. Jorge Rubem Folena de Oliveira

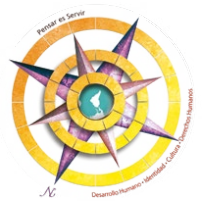


framing the crimes of disobedience and contempt practiced against military people. The investigation took place through qualitative analysis of trials at the Superior Military Court, between the years 2011 to 2019, which resulted in condemnations for disobedience and contempt, in the course of operations for Guarantee of Law and Order used against residents of slum communities in Rio de Janeiro, who rose up against the armed forces' police action.

Keywords: Military Justice. Colonialism. Subalternity. GLO. Guarantee of law and order. Resistance and contempt.

\section{Introdução}

Existe uma infeliz tradição latino americana pela qual os militares têm colaborado de forma direta ou indireta em golpes de Estado e participado ativamente em regimes antidemocráticos, como visto em 2019 na Bolívia, quando os militares se omitiram de assegurar o regime constitucional e abriram caminho para o afastamento do presidente legitimamente eleito antes do término do seu mandato.

Os militares, em muitos países do continente sul-americano, são vistos como forças pretorianas em defesa dos interesses patrimoniais da classe dominante, que, por terem uma vida de camaradagem de caserna, colocam-se num grande distanciamento social das camadas populares, de onde são recrutados.

No Brasil, durante o período republicano iniciado em 1889, os militares têm sido agentes atuantes na políti$\mathrm{ca}$, assumindo diretamente o poder no final do regime imperial (18221889), participando e colaborando com a derrubada de governos civis, como ocorrido em 1930 (Washington Luís), em 1945 (Getúlio Vargas), em 1964 (João Goulart) e em 2016 (Dilma Rousseff).

Além disso, há registros de atuação das forças militares brasileiras em combate direto contra a população civil, a exemplo do que ocorreu nos massacres da "guerra de Canudos" (1896-1897), no "caldeirão do Santa Cruz do Deserto" (1937) e também durante o regime de 1964-1985, em que civis foram presos, torturados, desaparecidos e mortos.

Tendo em vista o protagonismo militar no país, inclusive na vida política, na qual se consideram indevidamente como uma espécie de "poder moderador", a Justiça Militar, que deveria ser empregada, em tempos de paz, exclusivamente para o julgamento de militares em assuntos relacionados ao exercício da profissão 
nas atividades da caserna, tem sido direcionada para o julgamento de civis, inclusive para fins de perseguição política, como ocorrido no Brasil a partir de 27 de outubro de 1965, com a introdução pelo regime ditatorial de 1964-1985 do Ato Institucional número 02 (BRASIL, 1965), que, em seu artigo $8^{\circ}$, transferiu para o Superior Tribunal Militar a competência para processar e julgar crimes considerados de natureza política pelo regime.

A partir da década de 2010, as Forças Armadas têm sido empregadas em diversas operações de Garantia da Lei e da Ordem, em decorrência das quais passaram a atuar em auxílio e complementação aos órgãos de segurança pública em "operações de pacificação" de comunidades pobres e faveladas, no Rio de Janeiro, como na Favela da Maré e dos morros do Complexo do Alemão.

Em razão deste tipo de atuação dos militares, nessas operações em comunidades pobres e reiteradamente abandonadas pelo Poder Público, surgiram conflitos e ações de resistência por parte da população civil, que não aceitou que as Forcas Armadas atuassem como órgãos de policiamento ostensivo, o que gerou diversas autuações de civis por desobediência e desacato, resultando em prisões, processos criminais e condenações por parte da Justiça Militar brasileira.

Assim, o objetivo deste artigo será analisar o processamento de civis (na sua maioria pobres, negros e favelados no Rio de Janeiro), por parte da Justiça Militar, em decorrência do cumprimento de operações de Garantia da Lei e da Ordem (GLO), por enquadramento nos crimes de desacato (artigo 299 do Código Penal Militar ${ }^{1}$ ) e desobediência (artigo 301 do Código Penal Militar² ${ }^{2}$, praticados contra a instituição e a "administração militar".

É possível afirmar, como hipótese, que o Superior Tribunal Militar tem construído a sua jurisprudência, mediante o estabelecimento de condenações por desobediência e por desacato contra moradores de comunidades de favela, para assegurar a simbologia de uma suposta superioridade da instituição militar sobre a sociedade civil, a fim de dar prosseguimento à tutela militar iniciada em 1889.

1 “Artigo: 299. Desacatar militar no exercício de função de natureza militar ou em razão dela:

Pena: detenção, de seis meses a dois anos, se o fato não constitui outro crime."

2 "Artigo 301: Desobedecer a ordem legal de autoridade militar.

Pena: detenção até seis meses.”

38 Justiça militar brasileira: persecução contra civis negros, pobres e favelados em operação de garantia da lei e da ordem no Rio de Janeiro Dr. Jorge Rubem Folena de Oliveira

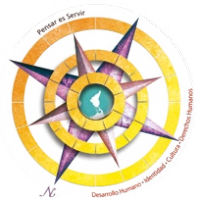


Com efeito, para fins de método, serão analisados, de forma qualitativa, acórdãos do Superior Tribunal Militar, proferidos entre os anos de 2011 a 2019, em particular nos casos decorrentes de operações de Garantia da Lei e da Ordem empregadas em favelas do Rio de Janeiro, em que moradores daquelas comunidades se insurgiram contra a atuação das Forças Armadas como força policial.

\section{Julgamento de civis pela Justiça militar no Brasil, um traço de colonialismo e subalternidade}

O sítio eletrônico do Superior Tribunal Militar (STM) afirma que, mesmo antes da independência do Brasil, em 1822, "pelo Alvará Régio com força de Lei de $1^{\circ}$ de abril de 1808 , D. João (VI) criou o Conselho Supremo Militar e de Justiça, que se tornou mais tarde o Superior Tribunal Militar e última instância da Justiça Militar da União" (BRASIL, 2020).

Como afirmam SOUZA e SILVA (2016), "a Justiça Militar brasileira foi um dos primeiros ramos formais do sistema de justiça a ser criado no país com a vinda da família real portuguesa em 1808. O ramo existe até hoje e desde (a Constituição de)
1934 integra o rol das justiças especiais do Poder Judiciário."

Uma das grande críticas formuladas contra a Justiça Militar é a sua utilização para o processamento e julgamento de civis em razão de perseguição política, para crimes não propriamente militares. Na verdade, uma Justiça Militar em tempo de paz somente se justificaria (quando muito) para julgar militares, no exercício de suas funções, em razão da rigidez da hierarquia e da disciplina da caserna.

Contudo, entendo que os militares, como quaisquer servidores públicos, deveriam ser processados e julgados pela Justiça Comum, sem influência do viés corporativo e protetivo, a que muitas vezes os julgamentos pelos mesmos pares conduzem.

A República, como instituição, tem por fundamento a igualdade e a transparência; assim, não se justifica uma justiça punitiva exclusivamente para os militares, aos quais deveria ser dispensado o mesmo tratamento que a qualquer outro servidor público.

Porém, desde o Império, civis vêm sendo julgados e condenados por órgãos militares, como forma de repressão direcionadas contra ações contestatórias e de rebelião, 
promovidas por movimentos populares. Souza e Silva (2016) registram que

a partir de 1824, após a polêmica repressão à Confederação do Equador, sem uma definição precisa do foro militar, quando necessário, os Conselhos de Guerra poderiam ser usados na repressão a movimentos populares, punindo também civis. Como tribunal de exceção, a Comissão Militar era um dispositivo acionado para dar ares de julgamento à ação do Estado na repressão a movimentos contestatórios.

Esse comportamento foi intensificado em diversos períodos da $\mathrm{Re}$ pública, seja na sua fundação, com a perseguição de simpatizantes do superado regime monárquico (SOUZA e SILVA, 2016), como durante os anos da Revolução de Trinta ${ }^{3}$, quando foram empregados inclusive tribunais de exceção, como o Tribunal de Segurança Nacional (TSN), em 1935, formado inicialmente por militares, para condenar comunistas (Teixeira da Silva, 2015).

3 Souza e Silva (2016): “A justiça militar não passaria ilesa à turbulência política da década de 1930. Em novembro de 1931, o Governo Provisório baixou decreto (20.656, de 14/11/1931) determinando o processo e julgamento pela justiça militar de militares, assemelhados ou civis que tomassem parte por qualquer forma nos atentados contra a ordem pública ou contra os governos da União e dos estados."
Durante a ditadura civil-militar de 1964-1985, a partir da edição do Ato Institucional número 02 (AI-2), a Justiça Militar foi empregada para perseguir e condenar civis, usando a acusação de prática de crimes políticos, contra a segurança nacional e a ordem econômica, sendo que "foi a primeira tentativa de institucionalizar o regime policial-militar, nos moldes da doutrina de segurança nacional." (Tércio, 2002, p. 61)

Superado o regime ditatorial de 1964-1985, a Nova República não teve força suficiente para se livrar da tutela dos militares, que vêm se impondo desde a fundação da República em 1889 (Teixera da Silva, 2020). Na Constituição de 1988, os militares conseguiram manter o seu inadequado poder moderador, representado pela Garantia da Lei e da Ordem (artigo 142) (Teixera da Silva, 2020), e lograram conservar a estrutura da Justiça Militar, que recebeu carta branca para processar e julgar civis, ficando estabelecido na Carta Constitucional apenas que fosse feito conforme previsto em lei, quando o constituinte poderia ter ressalvado, no Texto Maior, que os civis não deveriam ser julgados na justiça castrense.

Ou seja, a ordem política iniciada a partir de 1985, materializada

40 Justiça militar brasileira: persecução contra civis negros, pobres e favelados em operação de garantia da lei e da ordem no Rio de Janeiro Dr. Jorge Rubem Folena de Oliveira

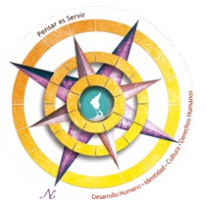


juridicamente por meio do processo constituinte de 1987-1988, foi incapaz de superar "o passado não resolvido" do Brasil (Folena de Oliveira, 2018), ao permitir que os militares pudessem interferir no destino da política e o emprego de tribunais militares para manter a repressão contra os civis; ou seja, tudo o que vem desde o período colonial, perpassa o Império e caminha por toda a República, ao ponto de, nos dias de hoje, moradores de favelas do Rio de Janeiro (pessoas simples e pobres) estarem sendo processados e condenados sob acusação de desobediência e desacato, por se insurgirem contra ações policiais realizadas por militares, em consequência das Operações de Garantia da Lei e da Ordem ${ }^{4}$.

Este traço de persecução contra civis, marcado por nítido conteúdo de criminalização dos atos de resistência e insubordinação de grupos sociais subalternos, revela a passividade da Justiça Militar, ao aceitar ser empregada para a repressão e isolamento social (constituição de "guetos") da população das favelas, no Rio de Janeiro, locais basicamente

4 STM - processos números 007937.2011.7.01.0201, 0264-88.2014.7.01.0201, 0170-43.2014.7.01.0201,

0229-

31.2014.7.01.0201, 0142-75.2014.7.01.0201, 0229-31.2014.7.01.0201, 019337.2014.7.01.0201, 0086-56.2015.7.01.0201, 0108-75.2015.7.01.0201. habitados por pessoas negras, mestiças e pobres.

Tanto o colocar-se a serviço para condenar civis, quanto o apresentar-se para realizar policiamento ostensivo (como fizeram as Forças Armadas, ao aceitarem executar as operações de Garantia da Lei e da Ordem nas favelas do Rio de Janeiro), revelam uma busca de reafirmação aristocrática de honorabilidade, que parece nortear a formação militar (Mayer, p. 186).

Esse comportamento de busca de superioridade e reafirmação por honorabilidade, realizado por forças militares, cujos integrantes, na maioria, são pessoas oriundas da mesma classe social explorada (Fanon, 2008, p. 34), faz surgir um grave conflito pelo questionamento da ação militar por parte de alguns moradores de favelas e bairros pobres, que vivem em constante "estado de defesa, sob alerta" (Gramsci, 2014, p. 135) na sua luta contra a subalternidade.

Portanto, o emprego do aparato da Justiça Militar para processar, julgar e condenar civis é uma marca do colonialismo, que ainda se faz presente na repressão das forças sociais insurgentes, seja em razão de consequências políticas, ideológicas, econômicas, sociais e raciais, que ainda são marcantes na sociedade brasileira. 
Consideramos importante registrar que o Brasil foi o último país das Américas a dar fim à escravidão formal, em 1888. Sendo ainda digno de nota que somos "um dos poucos países democráticos da América Latina a manter um foro militar, com características corporativas, acrescidas da possibilidade de julgar civis." (Souza e Silva, 2016)

\section{Garantia da lei e da ordem}

Nos últimos dez anos, o Governo Federal decretou diversas operações de Garantia da Lei e da Ordem (GLO), prevista no artigo 142 da Constituição Federal (BRASIL, 1988), em razão de pedidos de governadores de Estados para que os militares pudessem auxiliar os órgãos de segurança pública, definidos no artigo 144 da Constituição Federal (Brasil, 1988), que se revelaram incapacitados para assegurar a preservação da ordem pública e da incolumidade das pessoas e do patrimônio (Folena de Oliveira, 2017).

É imperativo que a Garantia da Lei e da Ordem (GLO) pelas Forças Armadas somente pode ocorrer se houver o efetivo esgotamento dos órgãos responsáveis pela Segurança Pública, no caso as polícias, como previsto nos $\S \S 2^{\circ}$ e $3^{\circ}$ do artigo
15 da Lei Complementar 97/1999 (BRASIL, 1999).

O $\S 4^{\circ}$ do artigo 15 da Lei Complementar 97/1999 (BRASIL, 1999) dispõe que, ativada a GLO, o emprego operacional das Forças Armadas "ocorrerá de forma episódica, em área previamente estabelecida e por tempo limitado, em ações de caráter preventivo e repressivo necessárias para assegurar o resultado das operações da garantia da lei e da ordem".

Nesse ponto, é importante realçar que as Forças Armadas passam a atuar como órgão policial, cumprindo excepcionalmente o mesmo papel das forças de segurança pública, que são auxiliadas pelos militares. Ou seja, não deveria ser tratada como um estado de guerra; sendo assim, não se justifica o emprego do aparato militar de natureza bélica, inclusive com utilização de carros de combate etc.; sendo a ação militar de mero reforço policial dos órgãos de segurança, a quem efetivamente cabe a defesa patrimonial e incolumidade das pessoas.

Ocorre que, durante as GLO(s), têm ocorrido diversos conflitos entre os integrantes das Forças Armadas em operações de policiamento e civis, inclusive com a morte de pessoas inocentes.

42 Justiça militar brasileira: persecução contra civis negros, pobres e favelados em operação de garantia da lei e da ordem no Rio de Janeiro Dr. Jorge Rubem Folena de Oliveira

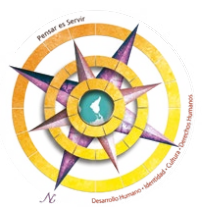


Como decorrência, muitas vezes, moradores dessas áreas sob intervenção, têm sido presos em flagrante e autuados criminalmente, sob a alegação de prática de desacato e desobediência, sendo processados e julgados na Justiça Militar; inclusive, as condenações são impostas aos civis porque tais delitos são considerados como de natureza militar, conforme entendimento firmado pelo Supremo Tribunal Federal, que não acolheu habeas corpus em que se defendia a competência do Juizado Especial Criminal e manteve a competência da Justiça Militar neste tipo de acusação (BRASIL,2013).

Desta forma, temos civis (pobres, negros e favelados) sendo julgados pela Justiça Militar, a partir de acusações formuladas exclusivamente por agentes militares, em processos nos quais, na maioria das vezes, somente o testemunho dos militares é suficiente para a condenação a ser imposta:

$\mathrm{O}$ fato de as testemunhas presenciais se confundirem com os próprios ofendidos não tem o condão de desmerecer, tampouco reduzir o potencial comprobatório de suas declarações. Suas palavras são dotadas de presunção de legitimidade e de legalidade, sendo merecedoras de crédito, inclusive no tocante à incriminação de pessoa envolvida no episódio delitivo ${ }^{5}$.

\section{Justiça Militar e sua com- petência para julgar civis}

A Justiça Militar, nos termos do artigo 122 da Constituição Federal (BRASIL, 1988), tem entre seus órgãos o Superior Tribunal Militar e os Tribunais e os Juízes Militares instituídos por lei, para "processar e julgar os crimes militares definidos em lei", conforme dispõe o artigo 124 da Constituição Federal (BRASIL, 1988).

Além disso, o parágrafo único do artigo 124 da Constituição Federal (BRASIL, 1988) prevê que a lei irá dispor sobre a organização, o funcionamento e a competência da Justiça Militar.

Vemos assim que o constituinte deixou a definição do crime militar e o seu respectivo processamento pela Justiça Militar para a legislação infraconstitucional; sendo que, na tradição brasileira, o fórum militar tem sido empregado para o processamento de civis, inclusive para perseguição política, além do emprego das forças militares na repressão dos movimentos

5 STM, processo número 000026488.2014.7.01.0201, relator Ministro Gen. Ex. Marco Antônio de Farias. 
populares, como acima demonstrado na introdução deste trabalho.

No caso brasileiro, até hoje não foram regulamentados os dispositivos constitucionais acima mencionados, aplicando-se, por recepção, o Código Penal Militar e o Código de Processo Penal Militar, respectivamente, Decreto-lei 1.001/1969 (BRASIL， 1969-a) e 1.002/1969 (BRASIL, 1969-b), oriundos do regime civil-militar de 1964-1985, impostos à época por meio da Junta Militar que governou o Brasil, formada pelos Ministros da Marinha, Exército e Aeronáutica, conforme poderes atribuídos pelo Ato Institucional número 16/1969 (BRASIL, 1969-c), considerado um dos entulhos ditatoriais.

O Código Penal Militar, em seu artigo $9^{\circ}$, inciso III, alínea "d", considera crime militar, em tempo de paz, "os crimes praticados (...) por civil, contra instituições militares (...) nos seguintes casos: (...) d) ainda que fora do lugar sujeito à administração militar, contra militar em função de natureza militar, ou no desempenho de serviço de vigilância, garantia e preservação da ordem pública, administrativa ou judiciária, quando legalmente requisitado para aquele fim, ou em obediência a determinação legal superior."
Assim, pela letra da lei do regime ditatorial, o civil poderá ser responsabilizado por crime militar se atentar contra as instituições militares (sendo assim considerada, inclusive, a pessoa do militar que esteja atuando com violência), mesmo que fora de local militar, em serviço de preservação da ordem pública.

Ou seja, é a naturalização do autoritarismo contra a população, para a manutenção da tutela militar sobre a ordem política civil. É a validação da autorização para os militares estenderem suas condutas para além dos limites dos quarteis, o que é inadmissível numa ordem democrática, na qual deve prevalecer o poder civil.

Com efeito, o Supremo Tribunal Federal (STF), ao convalidar uma interpretação decorrente da aplicação de uma norma do regime ditatorial de 1964-1985, abriu o caminho para o processamento de civis pobres, moradores de favelas do Rio de Janeiro, pela Justiça Militar, conforme jurisprudência construída pelo Superior Tribunal Militar.

Porém, esse mesmo entendimento permite que, no momento atual, os membros da Suprema Corte sejam ameaçados por diversos agentes políticos, de origem militar, saudosos do regime dos "anos de chumbo", que

44 Justiça militar brasileira: persecução contra civis negros, pobres e favelados em operação de garantia da lei e da ordem no Rio de Janeiro Dr. Jorge Rubem Folena de Oliveira

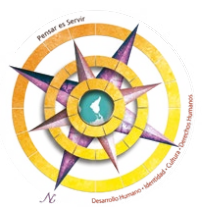


consideram as instituições militares um dogma sagrado, posicionado acima da Constituição e do povo, e usam a interpretação da Carta Maior para atingir e preservar seus interesses.

\section{Superior Tribunal Militar e o julgamento de civis por desobediência e desa- cato em GLO no Rio de} Janeiro

O Superior Tribunal Militar (STM) é um tribunal de revisão das decisões proferidas pela primeira instância da Justiça Militar; é um órgão composto por 15 julgadores, sendo 10 militares (4 generais do Exército, 3 almirantes da Marinha e 3 brigadeiros da Aeronáutica) e 5 civis, com formação jurídica (3 oriundos da advocacia, 1 da magistratura militar e 1 da procuradoria de justiça militar).

De 2011 a 2019, há diversos julgamentos de recursos no Superior Tribunal Militar, em que civis foram condenados por desobediência e/ ou desacato, por terem se insurgido contra a autuação dos militares das Forças Armadas no policiamento ostensivo, em comunidades de favelas do Rio de Janeiro, em decorrência de Operação de Garantia da Lei e da Ordem.
O que chama a atenção nesses julgamentos é a forma como a "instituição militar" das Forças Armadas se impõe sobre o poder civil, de modo a justificar o processamento e o julgamento pela Justiça Militar das pessoas que se rebelaram, a exemplo do que ocorreu em diversas passagens da História brasileira, em que essa justiça foi empregada para perseguir cidadãos; que segue sendo utilizada contra negros, mestiços e pobres, e que é aceito com passividade por parte dos oficiais militares, que passaram a atuar na ordem interna como aparelho repressivo contra os indivíduos de agora, muitos deles descendentes dos escravos de outrora.

Assim, a perseguição realizada no passado pelos capitães do mato contra escravos rebelados se mantém presente; sendo, nestes casos, utilizado como argumento para justificar as prisões, o potencial de ofensa à instituição militar, supostamente violentada pelos civis insurgentes.

No processo referente à apelação $\mathrm{n}^{\circ}$ 7000050-50.2019.17.00.0000, cujo relator foi o Gen. Ex. Odilson Samapio Benzi, o acusado respondeu à ação penal porque, em 20/08/2016, não reconheceu os militares, em patrulhamento, como força policial: 
O denunciado não obedeceu à ordem, alegando que não acompanharia os militares por não serem eles polícia.

Diante da recusa, (...) o conduziu até a faixa de areia e tentou iniciar a revista pessoal, momento em que o denunciado se alterou, insistindo que não aceitava ser revistado.

Em razão do comportamento do denunciado, (...) lhe determinou que se colocasse de joelho para a realização da revista, tendo este novamente recusado.

(...) Entretanto, o denunciado permanecia alterado e em oposição à revista, dizendo ao (militar) 'vai tomar no ..., ao que lhe foi dada voz de prisão e encaminhado à Delegacia Judiciária Militar, tendo sido necessário o uso de algemas para contê-lo."

O STM não levou em consideração possível provocação dos militares, mas apenas que o denunciado empregou "conotação pejorativa das palavras proferidas, desprezando o militar em serviço, em nítida finalidade de humilhar, menosprezar, aviltar, rebaixar a autoridade da vítima (o militar), e, consequentemente, a função militar exercida por ela, caracterizando o dolo inerente ao delito de desacato, não sendo de considerar o mero estado de exaltação.
No julgamento, não foi considerada nenhuma possibilidade de humilhação do denunciado, que foi colocado de joelhos para ser revistado, mas tão somente as ofensas que foram eventualmente disparadas contra o ofendido e a "função militar", num nítido caráter de proteção da instituição e do corpo militar.

No processo referente à apelação $\mathrm{n}^{\mathrm{o}}$ 264-88.2017.7.10.0201/RJ, cujo relator foi o ministro Gen. Ex. Marco Antônio de Farias, decorrente de ação ocorrida em patrulhamento no Complexo do Alemão, em 24/10/2014, o Tribunal entendeu que:

...O emprego dos militares federais em operação de Garantia da Lei e da Ordem $(G L O)$ é legítimo, embora, para alguns desavisados, receba a interpretação de constituir atividade precípua de segurança pública. (...) O bem jurídico tutelado pelo art. 299 do CPM (crime de desacato) é a ordem administrativa militar. Ao Estado é atribuída a qualidade de ofendido mediato, conquanto os militares envolvidos no patrulhamento encontram-se na condição de seus mandatários, em missão oficial.

Da mesma forma, no processo referente à apelação $\mathrm{n}^{\circ} 0170$ 43.2014.7.01.0201, cujo voto vencedor foi do ministro Alte. de Esq. Marcus Vinicius Oliveira dos

46 Justiça militar brasileira: persecução contra civis negros, pobres e favelados em operação de garantia da lei e da ordem no Rio de Janeiro Dr. Jorge Rubem Folena de Oliveira

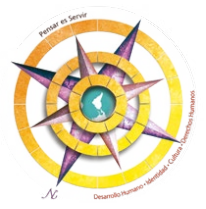


Santos. Neste caso, em 14/07/2014, os militares da força de pacificação da Maré fizerem revista pessoal no acusado, que:

insatisfeito com uma revista pessoal, desacatou-os, além de resistir à prisão, uma vez que, conforme narrado na denúncia, ao receber ordem para abrir as pernas a fim de que fosse terminada a revista, o denunciado passou a debater-se a fim de impedir que a revista continuasse.

O Tribunal entendeu no mencionado julgado acima que:

pratica os crimes de resistência mediante ameaça ou violência e de desacato a militar, o Civil que, ao ser abordado por militares da Força de Pacificação, no Rio de Janeiro, se opõe à execução de ato legal ao receber ordem para ser revistado, resiste à prisão, desfere palavras de baixo calão aos integrantes da corporação, bem como empurra e ameaça militar no cumprimento de sua missão. (...) Tal delito atinge diretamente a autoridade da administração militar.

Pelas decisões acima, a ofensa proferida pelo civil que, por qualquer comportamento, questiona a ação meramente de polícia da força militar, é direcionada contra a ordem "administrativa militar"; ou seja, a ofensa é contra a instituição militar, que não admite ser questionada, o que revela um traço de autoritarismo e superioridade sobre a sociedade civil.

No processo referente à apelação $\mathrm{n}^{\circ}$ 286-49.2014.01.7.0201/RJ, cujo relator foi o ministro Gen. Ex. Odilson Sampaio Benzi, foi apurado que:

... no dia 24 de setembro de 2014, o civil (...), durante a realização de uma abordagem por militares da Marinha do Brasil, integrantes da Força de Pacificação da Maré, foi preso em flagrante por ter proferido palavras ofensivas e efetuado gestos obscenos.

O Tribunal em razão disso, no caso acima, entendeu que:

Pratica o crime de desacato a militar previsto no artigo 299 do Código Penal Militar, o civil que, ao ser abordado por militares da Força de Pacificação, no Rio de Janeiro, desacata o militar no exercício de função de natureza militar ou em razão dela. A presença das Forças Armadas nas comunidades fluminenses foi acordada entre os poderes públicos e segue ditames legais, tendo inclusive o poder de polícia para abordar, revistar e prender quando em flagrante delito. 
No processo referente à apelação $\mathrm{n}^{\circ}$ 142-75.2014.01.7.0201/RJ, cujo relator foi o ministro Alt. Esq. Marcus Vinicius Oliveira dos Santos, apurou-se que:

... em 18 de junho de 2014, na localidade de Nova Holanda, no Complexo da Maré, (...) o acusado, acompanhado de sua esposa, chamou os soldados do Exército de 'periquitos' (...) além de ter cuspido nos pés do (...), comandante da Patrulha ...

O Tribunal, no mencionado caso, condenou o acusado sob o argumento de que "comete o crime de desacato o Réu que, de maneira livre e consciente, desrespeita militares que faziam ronda, chamando-os de 'periquitos e cospe por duas vezes nos pés do Ofendido.”

Como se pode denotar, há uma forte resistência da população das favelas contra a presença dos militares da “força de pacificação". Daí a sucessiva quantidade de casos de desobediência e desacato, sendo a atuação policial dos militares desnecessária para a garantia de lei e da ordem, servindo mais aos propósitos repressivos das Forças Armadas contra a população pobre das comunidades faveladas, que, ao externar o seu descontentamento, manifesta uma forma de resistência subalterna.

\section{Conclusão}

O que se pode constatar é que o emprego de forças militares em operações de Garantia da Lei e da Ordem, apesar do respaldo constitucional, legal e jurisprudencial do Supremo Tribunal Federal, encontra forte resistência no meio da população pobre, negra, mestiça e marginalizada das comunidades faveladas, que não encontraram nas Forças Armas qualquer amparo de proteção, mas tão somente mais repressão.

As Forças Armadas, por seu turno, aceitaram a missão, porém, diante da rejeição da comunidade, partiram para o enquadramento dos civis, que resistiram à sua ação policial, nas penas dos delitos de desobediência e desacato, que foram aplicados pela Justiça Militar, de modo a manter hígida a instituição e a administração militar. O que entendemos que somente poderia ser aplicado caso não estivesse ocorrendo um desvio de função das Forças Armadas, que tem aí uma ação tipicamente policial, própria dos órgão de segurança pública.

É possível concluir, assim, que o Superior Tribunal Militar construiu a sua jurisprudência, com condenações por desacato e desobediência aplicadas contra os moradores de

48 Justiça militar brasileira: persecução contra civis negros, pobres e favelados em operação de garantia da lei e da ordem no Rio de Janeiro Dr. Jorge Rubem Folena de Oliveira

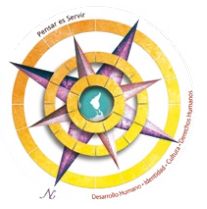


comunidades e favelas, para assegurar a simbologia de uma suposta superioridade da instituição militar sobre a sociedade civil, a fim de manter a tutela militar e, assim, justificar a atuação das Forças Militares diante da sociedade, mesmo que seja como força de repressão e não de garantia da soberania nacional.

Por fim, ressalto que os militares, como quaisquer servidores públicos, deveriam ser processados e julgados pela Justiça Comum, sem influência do viés corporativo e protetivo, a que muitas vezes os julgamentos pelos mesmos pares conduzem.
A República, como instituição, tem por fundamento a igualdade e a transparência; assim, não se justifica uma justiça punitiva exclusivamente para os militares, aos quais deveria ser dispensado o mesmo tratamento que a qualquer outro servidor público.

Com certeza, isto poderia evitar julgamentos com resultados injustos, como ocorreu no caso do capitão Jair Messias Bolsonaro, que, no passado, foi expulso da sua corporação militar e processado por acusações de "conduta irregular" e prática de "atos que afetam a honra pessoal, o pundonor militar e o decoro da classe", mas terminou absolvido pela Justiça Militar (Carvalho, 2018).

\section{Referências}

Barreto Souza, A. e Moreira Domingues da Silva, A. (2016). A organização da Justiça Militar no Brasil: Império e República. Estudos Históricos, 29 (58).

BRASIL. (1965). Ato Institucional n.02, de 27 de out. 1965. Disponível em http://www.planalto.gov.br/ccivil_03/AIT/ait-02-65.htm Acesso em 29 de mai. 2020.

BRASIL. (1969-a). Decreto-lei 1.001, de 21 de out. de 1969. Disponível em http://www.planalto.gov.br/ccivil_03/Decreto-Lei/Del1001.htm Acesso em 28 de mai de 2020.

BRASIL. (1969-b). Decreto-lei 1.002, de 21 de out de 1969. Disponível em http://www.planalto.gov.br/ccivil_03/decreto-lei/Del1002.htm Acesso em 28 de mai. 2020.

BRASIL. (1969-c). Ato Institucional n. 16, de 14 de out. 1969. Disponível em http://www.planalto.gov.br/ccivil_03/AIT/ait-16-69.htm Acesso em 30 de mai. de 2020.

BRASIL. (1988). Constituição da República Federativa do Brasil. Disponível em http://www. planalto.gov.br/ccivil_03/constituicao/constituicao.htm Acesso em 28 de mai. 2020.

BRASIL. (1997). Lei Complementar 97, de 09 de junho de 1999. Disponível em http://www. planalto.gov.br/ccivil_03/leis/lcp/lcp97.htm Acesso em 30 de mai. 2020. 
BRASIL. (2013). STF, 1a Turma, Habeas Corpus número 113.128-RJ, relator Ministro Roberto Barroso,julgado em 10/12/2013. Disponível em http://portal.stf.jus.br/processos/downloadPeca.asp?id=202073206\&ext $=$.pdf

BRASIL. (2020). STM. 212 anos da Justiça Militar da União. Disponível em https://www.stm.jus. br/informacao/agencia-de-noticias/item/10479-superior-tribunal-completa-212-anos-e-produz-video-sobre-sua-historia-e-funcionamento Acesso em 27 de mai. de 2020.

Carvalho Maklouf, L. (2018). O julgamento que tirou Bolsonaro do anonimato. O Estado de S. Paulo.

Fanon, F. (2008). Pele negra, máscara branca. Editora Universidade Federal da Bahia.

Folena De Oliveira, J. R. (2017). Militares e política. Jornal GGN. Acesso em 30 de mai. de 2020. https://jornalggn.com.br/analise/militares-e-politica-por-jorge-folena/

Folena De Oliveira, J. R. (2018). Memória, golpe e Direitos Humanos no Brasil, Revista Digital do Instituto dos Advogados Brasileiros, (39). Acesso em 29 de mai. 2020.

Folena de Oliveira, J. R. (2018). Memória, golpe e Direitos Humanos no Brasil. Revista Digital $n^{o}$ 39. https://digital.iabnacional.org.br/revista-digital-no-39/ memoria-golpe-e-direitos-humanos-no-brasil/

Gramsci, A. (2014). Cadernos do cárcere. v. 6. Rio de Janeiro: Editora Civilizações Brasileira.

Estudos Históricos (Rio de Janeiro) versão impressa ISSN 0103-2186versão On-line ISSN 2178-1494.

Estud. hist. (Rio J.) vol.29 no.58 Rio de Janeiro mai./ago. 2016 https://doi.org/10.1590/S217814942016000200003 ARTIGOS

A ORGANIZAÇÃO DA JUSTIÇA MILITAR NO BRASIL: IMPÉRIO E REPÚBLICA. The organization of Military Justice in Brazil: Empire and Republic https://jorgefolena. blogspot.com/2020/05/dez-hipoteses-para-tempos-alarmantes.html

Mayer, A. (1981). A força de tradição. A persistência do antigo regime (1848-1914). Companhia das Letras.

Souza, A. B. e Silva, Â. M. D. da. (Mai-Ago 2016). A organização da justiça militar no Brasil: império e república. Revista Estudos históricos, 29 (58). Acesso em 27 de mai. 2020.

Teixeira Da Silva, F. C. (2015). O Tribunal e a Lei de Segurança Nacional no Brasil, 1935/1937. Acesso em 30 de mai. 2020. http://ufrj.academia.edu/FranciscoCarlosTeixeiraSilva

Teixeira Da Silva, F. C. (2020). Dez hipóteses para tempos alarmantes para compreender e mudar o Brasil. Acesso em 30 de mai. de 2020.

Tércio, J. (2015). A espada e a balança: crime e política no banco dos réus. Zahar Editor.

50 Justiça militar brasileira: persecução contra civis negros, pobres e favelados em operação de garantia da lei e da ordem no Rio de Janeiro Dr. Jorge Rubem Folena de Oliveira

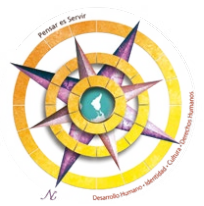

